\title{
Neutron Activation Analysis as a tool to Determine Concentration of Selected Metals in Table Salt Mined from Benya Lagoon, Ghana
}

\author{
Michael K. Vowotor ${ }^{1 *}$, Samuel S. Sackey², Charles L. Y. Amuah², Andrew Huzortey², \\ Dennis M. Ahorlu ${ }^{1}$, Godwin Kortey ${ }^{1}$, Dickson Kuvedzi ${ }^{1}$ \\ 1. Department of Physics, University of Cape Coast, Cape Coast, Ghana \\ 2. Laser and Fibre Optics Centre, Department of Physics, University of Cape Coast, Cape Coast, Ghana \\ * E-mail of the corresponding author: mvowotor@ucc.edu.gh
}

This project was funded by The Directorate of Research, Innovation and Consultancy (DRIC) and the Management of the University of Cape Coast. It was sponsored as a Group-led Research involving researchers from the Department of Physics during the third call for proposals for Research Support Grants (RSGs) in 2018

\begin{abstract}
Table salt is essential for life and if it contains metal impurities, it can affect the people that consume it. The Komenda Edina Eguafo Abrem municipality makes salt by evaporating brine from the Benya Lagoon. Benya lagoon is a lagoon known to be polluted due to various anthropogenic activities within its environs. The concentration of eight metals, Arsenic (As), Cadmium (Cd), Manganese (Mn) Lead (Pb), Aluminium (Al), Copper $(\mathrm{Cu})$, Magnesium $(\mathrm{Mg})$, and Vanadium $(\mathrm{V})$ have been determined in salt mined using water from the Benya lagoon. Salt samples were selected from five fixed-sampling stations and the concentrations of the metals determined using Neutron Activation Analysis. The ranges of the measured concentrations in the salts are as follows: 161.04-632.63 $\mathrm{mg} / \mathrm{kg}$ for Al, $0.001-0.004 \mathrm{mg} / \mathrm{kg}$ for As, $1.50-2.70 \mathrm{mg} / \mathrm{kg}$ for $\mathrm{Mg}, 49.14-3883.00 \mathrm{mg} / \mathrm{kg}$ for $\mathrm{Mg}, 17.24-110.96$ $\mathrm{mg} / \mathrm{kg}$ for $\mathrm{Mn}$, and $2.85-7.10 \mathrm{mg} / \mathrm{kg}$ for $\mathrm{V}$. An assessment according to the metal concentration marked $\mathrm{Mg}$ as the most abundant, whiles $\mathrm{Cd}$ and $\mathrm{Pb}$ the least being $0.001 \mathrm{mg} / \mathrm{kg}$ at all the five stations. Principal Component Analysis also established $\mathrm{Mg}$ to be the most abundant metal, and used to identify two major clusters; Group 1 (stations 4 and 5) and Group 2 (stations 1, 2 and 3). Group 2 recorded higher intensities of Mg. Using Pearson's correlation coefficient, significant correlations were drawn between $\mathrm{Al}$ and $\mathrm{Mg}(\mathrm{r}=-0.862), \mathrm{Mg}$ and $\mathrm{Mn}(\mathrm{r}=0.863)$ and $\mathrm{Mn}$ and $\mathrm{V}(\mathrm{r}=0.735)$, indicating the same or similar source inputs for each pair. Comparison with Codex Standard for Food Grade Salt showed that concentration values recorded for $\mathrm{Al}, \mathrm{Mg}$ and $\mathrm{Mn}$ were above recommended limits. The contamination factor $\left(\mathrm{C}_{\mathrm{F}}\right)$ and degree of contamination $\left(\mathrm{C}_{\mathrm{D}}\right)$ confirmed this level of contamination for $\mathrm{Al}, \mathrm{Mg}$ and $\mathrm{Mn}$ for all the five Stations, with Station 2 recording the highest Degree of Contamination. the least and corroborated salt from station 2 as most contaminated considering the combined toxicity at each station. Using an average daily salt intake of $6,000 \mathrm{mg}$, the mean daily intake of the elements when one consumes salt mined from the Benya lagoon was found to be above each element's Upper Tolerable Limit of its Recommended Dietary Allowable for the various Life Stage Groups. The associated Hazard Index suggests the probability of adverse effects when consumed. High standard deviation values for $\mathrm{Al}$ and $\mathrm{Mn}$ indicated the non-uniform spatial distribution of the individual metal contaminates at the various stations.
\end{abstract}

Keywords: Benya Lagoon; salt; heavy metal; contamination factor; degree of contamination, neutron activation analysis; recommended daily allowance, GHARR-1

DOI: $10.7176 / \mathrm{CMR} / 11-8-06$

Publication date:October $31^{\text {st }} 2019$

\section{Introduction}

Salt (sodium chloride, $\mathrm{NaCl}$ ) is required for life since everyone directly or indirectly. It functions as a preservative to both fresh and canned foods and is an essential additive to food as it improves taste. It is an essential nutrient for human health through its role as an electrolyte and osmotic solute and its industrial, medical and other uses are almost without number (Oria et al., 2013; United States Department of Agriculture [USDA], 2015). Its contamination with other metals, at certain levels, could therefore create serious risks (Soylak et al., 2008; Boppel, 1976; Musaiger et al., 2008; Nnorom et al., 2007; Amorim \& Ferrerira, 2005).

Currently, most refined salts are prepared from traditionally mined rock-salt or by refining salty sea water through purification and re-crystallization, after which various multiple phases of evaporation are employed to collect pure salt crystals (Cheraghali et al., 2010). The refining process leads to the precipitation of most of the contaminants, which are mainly magnesium and calcium salts. 
Bantuma, a suburb in Elmina, Ghana is well known centre for salt production using the salty water from the Benya lagoon. Machines are used to pump the water from the Benya lagoon, located within the Komenda Edina Eguafo Abrem (KEEA) municipality into manmade salt-ponds. The brine is produced from a mixture of water from the sea and the lagoon which is principally fed by sea water from the Gulf of Guinea. These two water bodies (lagoon and sea) are close to each other as shown in Figure 1.

This lagoon is of utmost importance to the municipality but it is polluted by activities such as the inflow of residual fertilizers and pesticide from farms as well as solid wastes such as metal scraps, iron filings and used car batteries from local auto-mechanic shops located along the banks of the lagoon (Armah et al., 2010). Also typically in this district, fishermen keep their treated wood meant for boat construction in the open and close to the lagoon. After rains, the chemicals used to treat the wood wash straight into the lagoon (Armah et al., 2010). Some of the ponds are also constructed just along the major highway and are therefore exposed to pollution as a result of the immense vehicular movements. This lagoon is fast drying up as a result of its heavy pollution (Vowotor et al., 2014) and has been reported by the Environmental Protection Agency (EPA), Ghana, to be one of the polluted lagoons in the country (Schmermer, 2011).

All of such activities ultimately introduce contaminants including toxic elements (heavy metals) into the evaporation salt-ponds. Figure 2 is a composite showing (a) the unhealthy surroundings around the salt ponds filled with lagoon water, (b) treated wood left in the open around the salt-ponds, (c) fishing net with lead ingots attached, (d) some harvested salt packed in sacks ready to be sold.

This study is to assess if the unhealthy practices and activities specifically involving toxic contaminants around the lagoon will be replicated in heavy-metal quantities in salt mined using water from the lagoon. This was by determining the concentrations of eight metals Arsenic (As), Cadmium (Cd), Manganese (Mn) Lead (Pb), Aluminium (Al), Copper (Cu), Magnesium (Mg), and Vanadium (V). All these are toxic at some concentration, but the definition of toxic metals makes the first four more toxic than the latter four (SRP Dartmouth Toxic Metals, 2018). The technique to be used in establishing the concentrations is Neutron Activation Analysis (NAA). The sources of these metals will also be ascertained by establishing the relationship between them, if any. NAA is a nuclear process used for determining concentrations of elements and allows for the sampling of elements as it disregards the chemical form of the sample, and focuses solely on its nucleus. Its strengths are that it needs no chemical preparation, is non-destructive and has very low detection limits for many elements. It can also be used for small sample sizes (1-200 mg) and can be used to analyse large number of elements simultaneously (Vowotor et al, 2012).

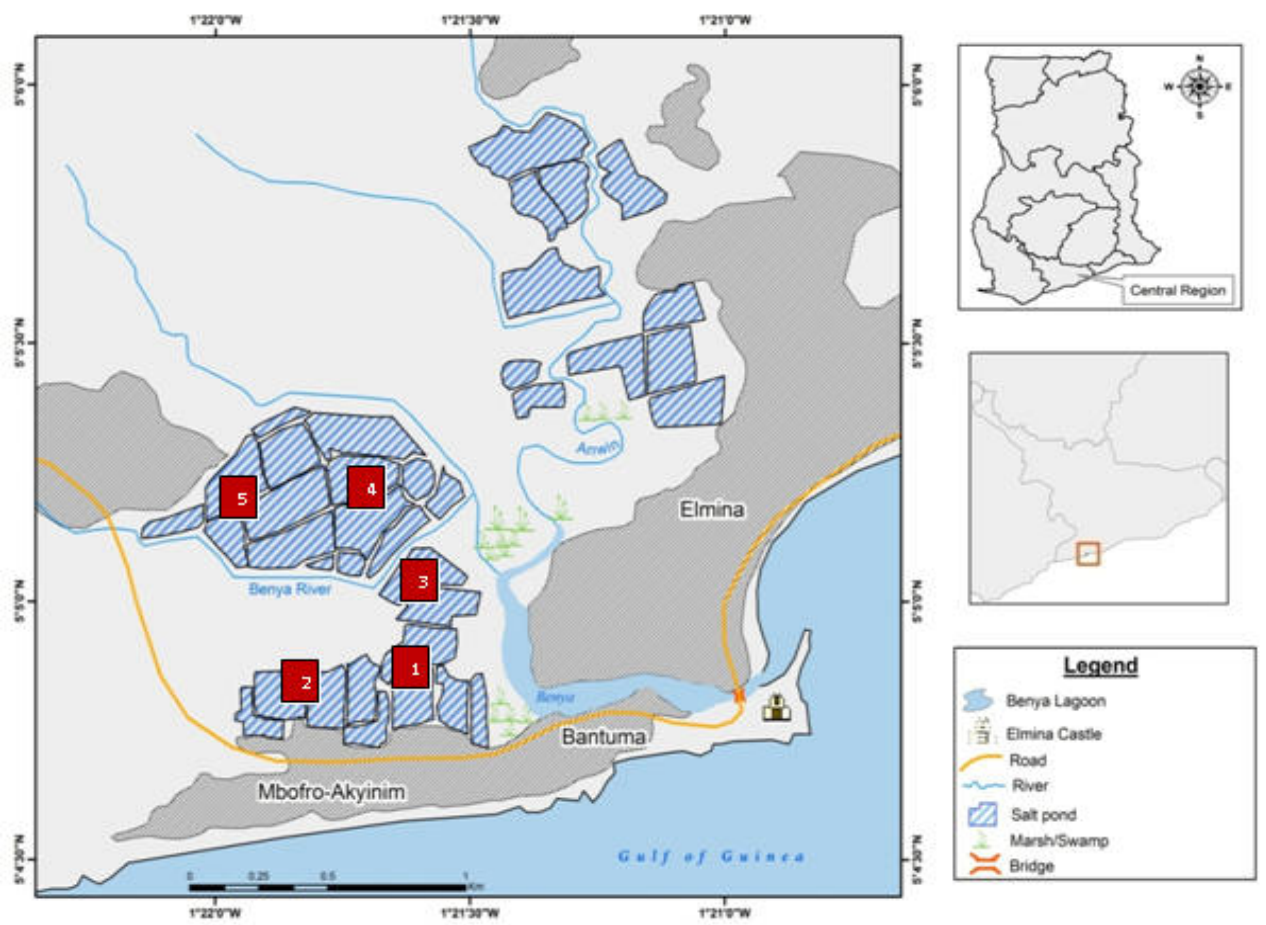

Figure 1. Map of Elmina (GIS, 2012) showing the close proximity of the Benya lagoon to the Gulf of Guinea. The sample selection stations of the evaporation salt-ponds are marked in red and numbered 1-5. 

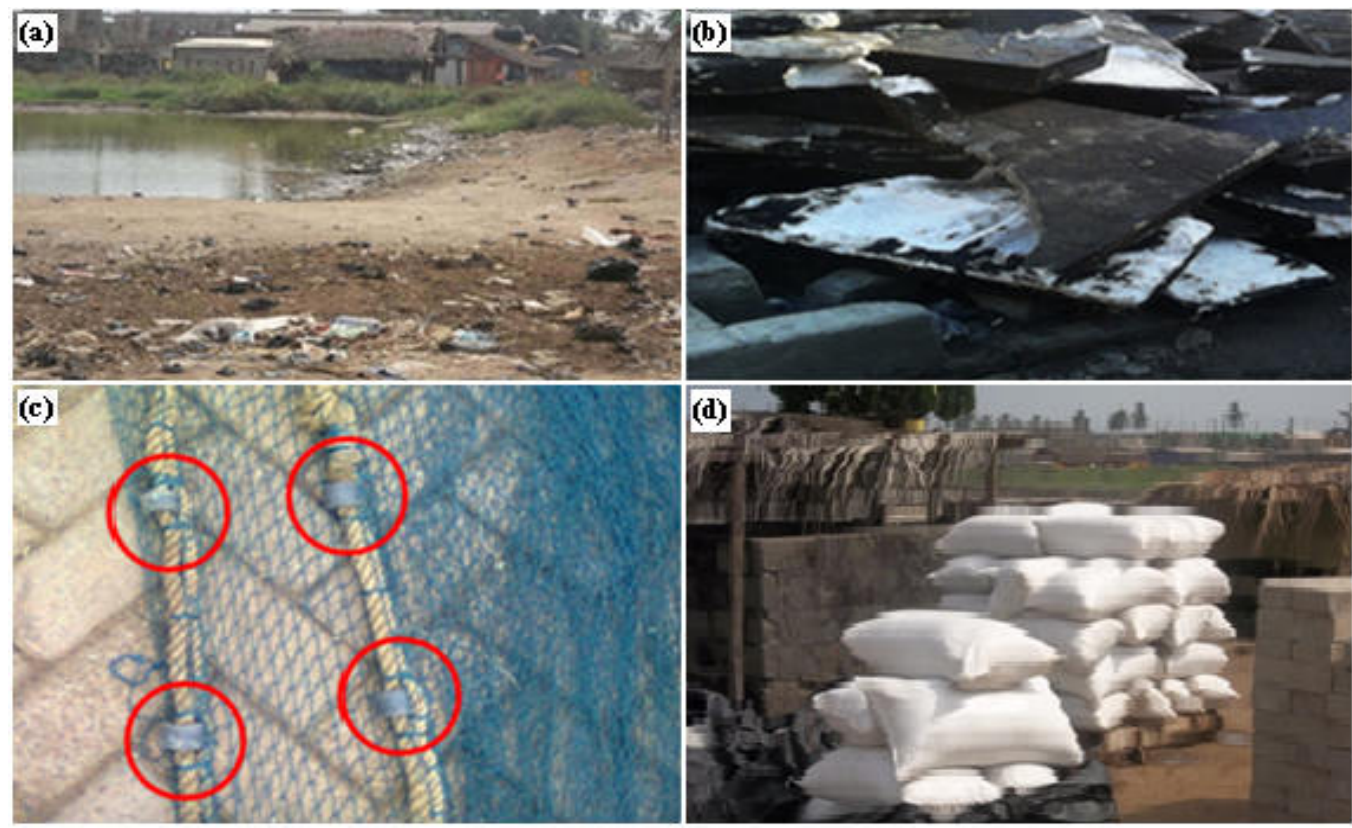

Figure 2. (a) A salt evaporation pond filled with lagoon water with its unhealthy environment

(b) Treated wood to be used for the construction of boats left close to the lagoon

(c) Fishing net with lead or metallic weights (circled in red)

(d) Some harvested salt packed in sacks and ready to be sold

\section{Methods}

\subsection{Study Area/Sampling}

Five fixed-sampling stations (1-5), as shown in Figure 1, were selected and marked for the study. The distance between any two ponds was between $100 \mathrm{~m}$ to $300 \mathrm{~m}$. Due to the nature of the lagoon and distance of the saltponds, a non-probability sampling technique was employed in the selection of the sample's stations.

All sampling equipment and containers used were pre-cleaned with acetone before and after use. Hydrochloric acid $(\mathrm{HCl})$ was again used to rinse the containers before placing the samples in them. Pre-cleaned blanks were tested and values obtained subtracted from the main values to compensate for background contamination (Vowotor et al, 2012).

The upper $10 \mathrm{~cm}$ from the surface of a salt-heap at each station was scooped with a pre-cleaned plastic spoon and placed in a plastic bowl. The process was repeated three times at different areas within each sample station and placed in the same bowl to form a composite sample. Each composite was mixed using a separate precleaned plastic spoon for homogeneity, after which it was placed in a plastic container, coded with indelible pen, and deposited in a labelled Ziploc bag to avoid cross contamination. All samples from the five stations were kept in an ice-chest and transported to the Ghana Atomic Energy Commission (GAEC) Preparation Laboratory for analyses using the Ghana Research Reactor-1 (GHARR-1) facility.

\subsection{Experimental Procedure and Validation}

The samples were shaken to ensure uniformity before weighing, after which they were further encapsulated into irradiation capsules (Rabbit capsule) of diameter $1.6 \mathrm{~cm}$ and height $5.5 \mathrm{~cm}$ and heat-sealed for neutron activation (irradiation). The prepared samples and reference standards were irradiated in the GHARR-1 facility using lightwater as moderator and coolant, and operated at $15 \mathrm{~kW}$ at a thermal neutron flux of $5 \times 10^{11} \mathrm{ncm}^{-2} \mathrm{~s}^{-1}$. The fuel source was highly enriched Uranium (90.2\%-Al alloy), metal beryllium used as reflectors and the reactor cooled by natural convection. The samples were transferred into the irradiation sites via pneumatic transfer system at a pressure of 0.6 MPa (Tandoh et al., 2009) with irradiation times ranging from $10 \mathrm{~s}$ to $1 \mathrm{~h}$ depending on the halflives of the elements of interest. For elements with relatively short half-lives such as $\mathrm{Mn}$, and V, with half-lives between $2 \mathrm{~min}$ and $3 \mathrm{~h}$, irradiation time was $10 \mathrm{~s}$ and counting time $10 \mathrm{~min}$. The samples were analyzed using irradiation schemes by optimizing irradiation time $\left(t_{i}\right)$, decay time $\left(t_{d}\right)$ and counting time $\left(t_{c}\right)$ based on the half-life of the respective elements. The irradiation scheme was $\left(\mathrm{t}_{\mathrm{i}}: \mathrm{t}_{\mathrm{d}}: \mathrm{t}_{\mathrm{c}}=0.5-2: 1: 10 \mathrm{~min}\right)$. For quality assurance, IAEA530 Trace element in tuna fish homogenate, Certificate of analysis standard material 1566b Oyster Tissue (National 
Institute of Standards and Technology, NIST), NIST 1547 Peach leaves, NIST 1515 Apple Leaves, NIST SRM 3132, NIST SRM 3131a and NIST SRM 3165 prepared in the same manner as the study samples were included. The Standard Reference Materials were treated the same way as the samples. Recoveries of the elemental concentrations ranged from $88 \%$ to $111 \%$ of the certified values.

\subsection{Evaluation of Peak Area of $\gamma$-Spectrum}

The counting of the induced radioactivity was performed using PC-based $\gamma$-ray spectrometry. The detector was an n-type high-purity Germanium (HPGe) sensor, model GR2518, and was coupled to a computer-based Multichannel Analyzer via electronic modules and a spectroscopy amplifier (model 2020, Canberra Industries Incorporated). The relative efficiency of the detector was $25 \%$, with an energy resolution of $1.8 \mathrm{KeV}$ at $\gamma$-ray energy of $1332 \mathrm{keV}$ of ${ }^{60} \mathrm{Co}$.

The $\gamma$-ray product radionuclides were qualitatively identified by the energies emitted and the quantitative analysis done by converting the counts as area under the photo-peaks using the comparator method. Using appropriate choice of cooling time, the detector's dead-time was controlled to be less than $10 \%$. Both qualitative and quantitative analyses were done using the $\gamma$-ray spectrum analysis software, MAESTRO-32 and WinSPAN2010 .

\section{Results}

The elements and their measured concentrations at the various sample selection stations are presented in Table 1.

Table 1: The mean measured concentration $(\mathrm{mg} / \mathrm{kg})$ at the various sample stations

\begin{tabular}{|c|c|c|c|c|c|c|c|c|}
\hline Stations & $\mathrm{Al}$ & $\mathrm{As}$ & $\mathrm{Cd}$ & $\mathrm{Cu}$ & $\mathrm{Mg}$ & $\mathrm{Mn}$ & $\mathrm{Pb}$ & $\mathrm{V}$ \\
\hline 1 & 474.82 & 0.001 & 0.001 & 2.70 & 3301.00 & 18.97 & 0.001 & 3.49 \\
\hline 2 & 632.63 & 0.001 & 0.001 & 1.98 & 3883.00 & 23.29 & 0.001 & 5.65 \\
\hline 3 & 333.19 & 0.001 & 0.001 & 1.50 & 2945.00 & 27.24 & 0.001 & 2.85 \\
\hline 4 & 177.02 & 0.004 & 0.001 & 1.50 & 1979.00 & 17.24 & 0.001 & 4.85 \\
\hline 5 & 161.04 & 0.001 & 0.001 & 1.56 & 49.14 & 110.96 & 0.001 & 7.1 \\
\hline $\mathrm{SD}$ & 200.752 & 0.001 & 0.000 & 0.517 & 1500.579 & 40.114 & 0.000 & 1.698 \\
\hline
\end{tabular}

SD represents standard deviation

\section{Discussions}

\subsection{Assessment According to Metal Concentration}

The continuous uptake of heavy metals results in its bioaccumulation in the body organs and tissues (Canli \& Atli, 2003). This is known to have adverse effects to human health and may cause renal failure, liver damage, cardiovascular diseases or even death (Al-Busaidi et al., 2011; Rahman et al., 2012).

Figure 3 is a composite graph in which (a) gives the abundance of the individual metals considering all the investigated stations and (b) their combined toxicity considering all the metals at each station. From Figure 3(a) $\mathrm{Mg}$ was the most abundant and $[\mathrm{Cd}]=[\mathrm{Pb}]$ the least, while from (b) it can be deduced that salt harvested from Site 2 had the highest concentration of metals. From Table 1 it can be deduced that the highest concentrations of $\mathrm{Al}$ and $\mathrm{Mg}$ were also recorded at Site 2. As explained, this may be assigned to the presence of car-fitting shops around this Site. The least cumulative concentration from Figure 3(b) was registered at site 5, despite the fact that the highest concentrations of $\mathrm{Mn}$ and $\mathrm{V}$ were registered at this same site (refer to Table 1). Our observation during the data collection was that some auto-mechanic shops were sited around this Station. It is worth noting that most piston-rods and crankshafts parts frequently used by such auto-mechanics are made from alloys toughened by Vanadium as it is often used as a steel-additive(RSC, 2015). The high standard deviation values obtained for $\mathrm{Mg}$, $\mathrm{Al}$, and $\mathrm{Mn}$ (refer to Table 1) indicate the non-uniform spatial distribution of the individual metal contaminates at the various sampling sites. 

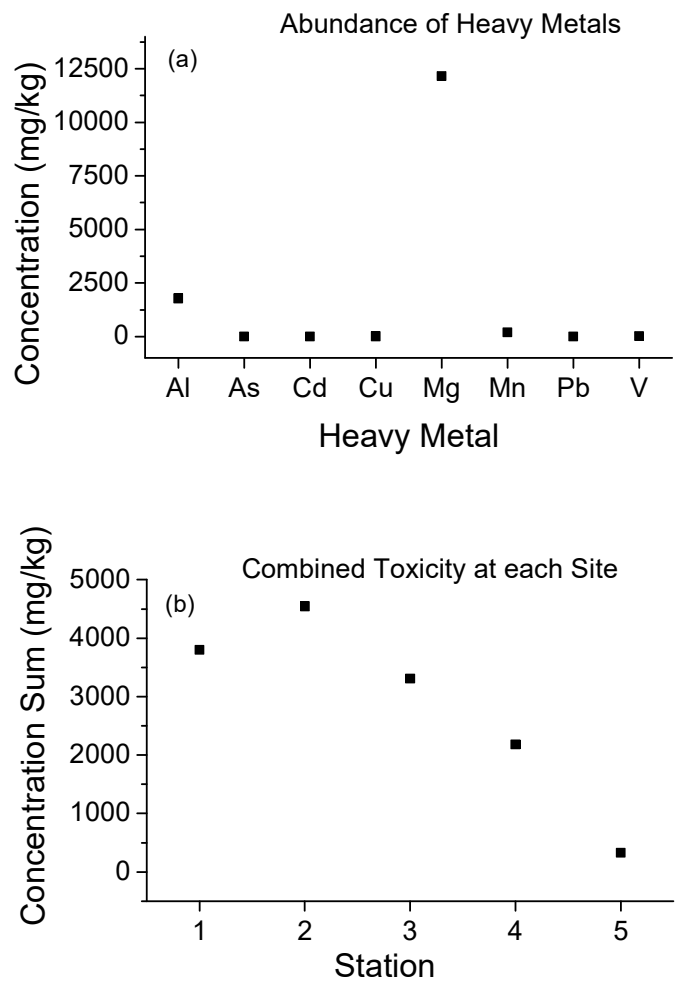

Figure 3. (a) Abundance of the individual metal impurities

(b) Combined toxicity at each station considering all the metal impurities

4.2 Multivan rate muanyss

Principal Component Analysis (PCA) is a widely used tool for multivariate analysis in which new 'axes' called principal components(PC) are determined by forming linear combinations of variables (measured parameter) using some mathematical methods. The first PC or PC1 will contain the maximum variance from the data; followed by PC2 and so forth (Bro \& Smilde, 2014).A PCA score plot will, therefore, show how the different observations (stations) are related while the loading plot will give further indication of how each of the variables (metal impurities) contributed to the similarities or dissimilarities between the stations.

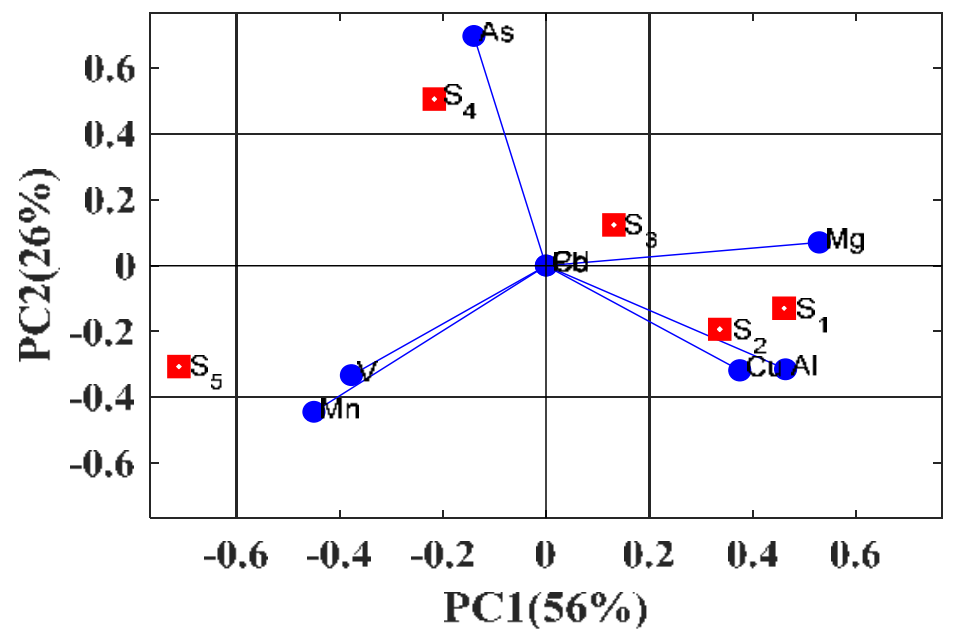

Figure 4. PC Biplot depicting the relationships between the stations (observations) and how the metal impurities (variables) contributed to the variations or similarities among the stations. 
In this study a PC Biplot which combines the scores and loadings in one plot (Bro \& Smilde, 2014)was used to enable easy and quick visualization of the relationships between the stations (observations) and how each of the metal impurities (variables) measured from the salts contributed to the variations or similarities among the stations. This is shown in Figure 4. From Figure 4 two groupings can be identified. The first group of stations (stations 4 and 5) are to the left of the PC1 axis (horizontal-axis) whiles the second group (Stations 1,2 and 3) are to the right. It can be inferred that since the second group of stations are to the right on the PC1 axis, then the major metal(s) causing the differences between these two groups is more in Stations 1, 2 and 3 than the other group of stations. The responsible metal impurity is $\mathrm{Mg}$ as it exhibits the maximum positive value along the PC1 axis

The contribution of all the other metal impurities can also be inferred. The metal impurities positioned at the origin of the $\mathrm{PC}$ Biplot $(\mathrm{Cd}$ and $\mathrm{Pb})$ have a neutral effect, whereas the metal impurities in the negative (As, Mn and $\mathrm{V}$ ) show an inverse relationship with the other metal impurities at the positive ( $\mathrm{Al}, \mathrm{Cu}$, and $\mathrm{Mg}$ ). Two very useful deductions can be made from Figure 4. The first is that it is possible to trace the particular station where salt was mined based on the measured levels of metal impurities. For instance, an unknown salt which has high levels of $\mathrm{V}$ and $\mathrm{Mn}$ but relatively lower levels in $\mathrm{Mg}, \mathrm{Cu}$, and $\mathrm{Al}$ is most likely to come from station 5 . The second deduction is that the type of metal impurities observed can be related to the activity that goes on around the station. For instance stations 1, 2, and 3 which occur to the right of the PC biplot have $\mathrm{Mg}$ as the most dominating metal impurity and is highly correlated with $\mathrm{Cu}$ and $\mathrm{Al} . \mathrm{Mg}$ is known to have the ability to improve mechanical, fabrication and welding characteristics when used as an alloying agent (especially with aluminum) and therefore used in the construction of cars (RSC, 2015). The physical presence of numerous car-fitting shops around sites 1 , 2 and 3 may explain the high concentration of $\mathrm{Mg}$ measured at these places.

\subsection{Assessment According to the Correlation between Elements}

Pearson's correlation coefficient was used to draw parallels between any two of the metal impurities. The matrix between the elements, shown in Table 2, gives information about their possible sources (Currie, 1991; Alfassi, 1994). The correlation coefficients which are significant at $90 \%$ confidence level, and could indicate the same or similar source inputs are highlighted and discussed.

Discharges from groundwater are important sources of nutrients, trace elements and contaminants to many types of coastal ecosystems (Kelly \&Moran, 2002). The Benya Lagoon is no exception as it receives contributions from numerous groundwater sources. Such variations in groundwater sources, as well as the indiscriminate discharge of wastes and hazardous activities around the lagoon bed, can contribute to the trace element's input. Accordingly, it is important to characterize each distinct source of trace elements and determine its contribution to the lagoon's ecosystem.

Table 2: Correlation Matrix between the Metal Impurities in the Salt Samples

\begin{tabular}{|c|c|c|c|c|c|c|}
\hline & $\mathrm{Al}$ & $\mathrm{As}$ & $\mathrm{Cu}$ & $\mathrm{Mg}$ & $\mathrm{Mn}$ & $\mathrm{V}$ \\
\hline $\mathrm{Al}$ & 1 & & & & & \\
\hline $\mathrm{As}$ & 0.498 & 1 & & & & \\
\hline $\mathrm{Cu}$ & 0.636 & -0.376 & 1 & & & \\
\hline $\mathrm{Mg}$ & $-\mathbf{0 . 8 6 2}$ & -0.169 & 0.515 & 1 & & \\
\hline $\mathrm{Mn}$ & -0.515 & -0.311 & -0.340 & $\mathbf{0 . 8 6 3}$ & 1 & \\
\hline $\mathrm{V}$ & -0.245 & 0.020 & -0.286 & -0.629 & $\mathbf{0 . 7 3 5}$ & 1 \\
\hline
\end{tabular}

The interpretation of the strength of the correlation coefficients usually depends on the researcher (Rumsey, 2010), so there are other strongly correlated elements with high coefficients of determination, hence cannot be ruled out and are highlighted and focus would be on the strength of relationship and while reporting statistical significance (Pallant, 2007). From Table 2, significant correlations can be drawn between the contaminants $\mathrm{Al}$ and $\mathrm{Mg}(\mathrm{r}=-0.862), \mathrm{Mg}$ and $\mathrm{Mn}(\mathrm{r}=0.863)$ and $\mathrm{Mn}$ and $\mathrm{V}(\mathrm{r}=0.735)$. These pair could each indicate the same or similar source inputs.

Elmina is a town where most activities are carried out along the banks of the Benya lagoon. There are lots of shops that deal and work with metal scraps, most of which are aluminum, iron, and lead, from all types of vehicles and machines. Magnesium is one-third less dense than aluminum and as mentioned, has the ability to improve the mechanical, fabrication and welding characteristics of aluminum when used as an alloying agent, and 
becomes useful in the construction of cars (RSC, 2015). The high levels of Al and Mg in the salt may be as a result of the activities of car mechanics along the banks of the lagoon.

Magnesium is again used as an anode material in primary batteries due to its high standard potential. Magnesium/manganese dioxide $\left(\mathrm{Mg} / \mathrm{MnO}_{2}\right)$ battery has twice the service life capacity compared to zinc/manganese dioxide $\left(\mathrm{Zn} / \mathrm{MnO}_{2}\right)$ battery of the same size and has a better ability to retain its capacity during storage, even at high temperature. $\mathrm{Mg} / \mathrm{MnO}_{2}$ are consequently more often used in the manufacture of car batteries as they are more durable form a protective cover on the surface of the magnesium anode(Electrical4u, 2015). A critical screening of the debris along the banks of the lagoon revealed the presence of used, spoilt and discarded car batteries. This practice can explain the high levels of magnesium and manganese in the mined salt.

About $80 \%$ of vanadium produced is used as a steel additive. Vanadium steel alloys are tough and used for the construction of tools, armour plates, axles, piston-rods and crankshafts which are all used in cars (RSC, 2015). Manganese in its pure state is too brittle to be of much use and as a result used in alloys such as steel. Steel, which has improved workability and resistance to wear, contains about $1 \%$ manganese. Manganese-steel contains about 13\% manganese (RSC, 2015). One can, therefore, infer that the high levels of Mn and V in the salt could have come from various car parts and can be assigned to the same activities of car mechanics operating along the banks of the lagoon.

\subsection{Assessment According to "Codex Standard for Food Grade Salt"}

The "Codex Standard for Food Grade Salt" (Codex, 2006) provides recommended limits for elements in salt, and for the food manufacturer, the conditions under which salt should be used as an ingredient of food or as a food additive and/or nutrient. Table 3 compares the mean concentrations measured for the metal impurities $( \pm$ standard deviation) with the Codex standard limits for some recognized institutions that have set standards and limits.

TABLE 3. Comparison of Metal Impurity Concentrations between Salt Samples Measured, Codex Standard Limit for Salt and Food Standard Limits $(\mathrm{mg} / \mathrm{kg})$

\begin{tabular}{|l|l|c|c|c|c|}
\hline & \multicolumn{1}{|c|}{ Measured mean } & $\begin{array}{c}\text { Codex } \\
\text { Standard } \\
\text { Limit For Salt }\end{array}$ & $\begin{array}{c}\text { Salt Standard } \\
\text { Limits } \\
\text { (FAO/WHO) }\end{array}$ & $\begin{array}{c}\text { Other } \\
\text { International Salt } \\
\text { Standard Limits }\end{array}$ & $\begin{array}{c}\text { Ghana } \\
\text { Standard } \\
\text { Salt Limits }\end{array}$ \\
\hline $\mathrm{Al}$ & $355.74 \pm 200.752$ & - & 1 & - & 0.5 \\
\hline $\mathrm{As}$ & $0.002 \pm 0.001$ & 0.5 & 0.5 & 0.5 \\
\hline $\mathrm{Cd}$ & $0.001 \pm 0.00$ & 0.5 & 0.5 & 2 \\
\hline $\mathrm{Cu}$ & $1.85 \pm 0.517$ & 2 & 2 & ${ }^{+} 0.1$ & - \\
\hline $\mathrm{Mg}$ & $2431.43 \pm 1500.579$ & - & - & ${ }^{++} 0.04$ & - \\
\hline $\mathrm{Mn}$ & $39.54 \pm 40.114$ & - & - & & 2 \\
\hline $\mathrm{Pb}$ & $0.001 \pm 0.00$ & 2 & - & & - \\
\hline $\mathrm{V}$ & $4.79 \pm 1.698$ & - & - & & 2 \\
\hline
\end{tabular}

(Codex, 2006), ${ }^{+}\left(\right.$Uganda Standard, 2006), ${ }^{++}($Loux, 2006)

It can be deduced from Table 3 that concentration values recorded for $\mathrm{Al}, \mathrm{Mg}$, and $\mathrm{Mn}$ were high compared to the Codex standard limits. As already explained, these elements are mainly present in most of the wastes discarded by car mechanics operating along the banks of the lagoon.

4.5 Assessment According to Contamination Factor $\left(C_{F}\right)$ and Degree of contamination $\left(C_{D}\right)$

The contamination factor $\left(\mathrm{C}_{\mathrm{F}}\right)$ reflects the extent of environmental contamination (Martin \& Maybeck, 1979)and was used to evaluate the possible anthropogenic input of metals in the salt. This factor is mathematically expressed in equation (1) as:

$$
\mathrm{C}_{\mathrm{F}}=\frac{\text { Measured Concentration }}{\text { Background Concentration }}
$$


The Background Concentration value of the metal is the combined standard limits set by the Codex Alimentarius Commission (Codex, 2006).

The degree of contamination $\left(\mathrm{C}_{\mathrm{D}}\right)$ was used to determine the contamination status and assesses the concentration of elements in the Salt (Martin \& Maybeck, 1979). Mathematically it is expressed in equation (2) as:

$$
\mathrm{C}_{\mathrm{D}}=\sum \mathrm{C}_{\mathrm{F}}^{\mathrm{i}}
$$

where, $\mathrm{C}_{\mathrm{F}}^{\mathrm{i}}$ is the contamination factor for the $i$-th element.

The four standard $\mathrm{C}_{\mathrm{F}}$ ranges, pollution grades, and intensities are given in Table 4 . The calculated $\mathrm{C}_{\mathrm{F}}$ and $C_{D}$ values for the metals are provided in Table 5, while the classification of the stations based on the extent of pollution is presented in Table 6 .

Table 4: $\mathrm{C}_{\mathrm{F}}$ Ranges and their pollution grades and Intensities (Martin \&Maybeck, 1979)

\begin{tabular}{|c|c|l|}
\hline $\mathrm{C}_{\mathrm{F}}$ & Grade & \multicolumn{1}{|c|}{ Intensity } \\
\hline $\mathrm{C}_{\mathrm{F}}<1$ & I & Low contamination factor \\
\hline $1 \leq \mathrm{C}_{\mathrm{F}}<3$ & II & Moderate contamination factor \\
\hline $3 \leq \mathrm{C}_{\mathrm{F}}<6$, & III & Considerable contamination factor \\
\hline $\mathrm{C}_{\mathrm{F}} \geq 6$ & IV & Very high contamination factor \\
\hline
\end{tabular}

Table 5: Calculated $\mathrm{C}_{\mathrm{F}}$ and $\mathrm{C}_{\mathrm{D}}$ values for the Metal Impurities investigated

\begin{tabular}{|c|c|r|r|r|r|r|r|r|}
\hline \multirow{2}{*}{ Stations } & \multicolumn{7}{|c|}{$\mathrm{C}_{\mathrm{F}}$, Contamination factor } & \multicolumn{1}{c|}{$\begin{array}{c}\mathrm{C}_{\mathrm{D}} \text {, Degree of } \\
\text { Contamination }\end{array}$} \\
\cline { 2 - 9 } & $\mathrm{Al}$ & $\mathrm{As}$ & $\mathrm{Cd}$ & $\mathrm{Cu}$ & $\mathrm{Mg}$ & $\mathrm{Mn}$ & $\mathrm{Pb}$ & 33960.4245 \\
\hline 1 & 474.82 & 0.002 & 0.002 & 1.35 & 33010 & 474.25 & 0.0005 & 30045.8745 \\
\hline 2 & 632.63 & 0.002 & 0.002 & 0.99 & 38830 & 582.25 & 0.0005 & 4005 \\
\hline 3 & 333.19 & 0.002 & 0.002 & 0.75 & 29450 & 681 & 0.0005 & 30464.9445 \\
\hline 4 & 177.02 & 0.008 & 0.002 & 0.75 & 19790 & 431 & 0.0005 & 20398.7805 \\
\hline 5 & 161.04 & 0.002 & 0.002 & 0.78 & 491.4 & 2774 & 0.0005 & 3427.2245 \\
\hline Mean & 355.74 & 0.0032 & 0.002 & 0.924 & 24314.3 & 988.5 & 0.0005 & \\
\hline
\end{tabular}

Table 6: Pollution grade and intensities for the 5 stations

\begin{tabular}{|c|c|c|c|c|c|c|c|c|}
\hline \multirow[b]{2}{*}{ Stations } & \multicolumn{7}{|c|}{$\mathrm{C}_{\mathrm{F}}$, Contamination factor } & \multirow{2}{*}{$\begin{array}{l}\mathrm{C}_{\mathrm{D}} \text {, Degree of } \\
\text { Contamination }\end{array}$} \\
\hline & $\mathrm{Al}$ & As & $\mathrm{Cd}$ & $\mathrm{Cu}$ & $\mathrm{Mg}$ & $\mathrm{Mn}$ & $\mathrm{Pb}$ & \\
\hline 1 & IV & I & I & II & IV & IV & I & $2^{\text {nd }}$ \\
\hline 2 & IV & I & I & I & IV & IV & I & $1^{\text {st }}$ \\
\hline 3 & IV & I & $\mathrm{I}$ & I & IV & IV & $\mathrm{I}$ & $3^{\text {rd }}$ \\
\hline 4 & IV & I & I & I & IV & IV & I & $4^{\text {th }}$ \\
\hline 5 & IV & I & I & I & IV & IV & I & $5^{\text {th }}$ \\
\hline Mean & IV & I & I & I & IV & IV & I & \\
\hline
\end{tabular}

Very high contaminations were recorded for $\mathrm{Al}, \mathrm{Mg}$, and $\mathrm{Mn}$ for all five Stations. $\mathrm{Cu}$ showed moderate 
contamination at Station 1 while the remaining stations exhibited low contaminations for the remaining tested metals. Station 2 recorded the highest Degree of Contamination while Station 5 recorded the least. This analysis is consistent with our observation with respect to the frequency and intensity of human activities along the banks of the lagoon as Station 2 experienced most of the human activities while Station 5 experienced the least.

\subsection{Assessment According to Dietary Reference Intake}

Dietary Reference Intakes are a set of guidelines for the daily intake of nutrients (as vitamins, protein, and fats) and other food components (as fibre). It comprises recommended dietary allowances (RDA), adequate daily intake (AI), values for nutrients having undetermined recommended daily allowances and tolerable upper level (UL) values of dietary reference intake (DRI) (Merriam-Webster Medical Dictionary, 2015).

Recommended Dietary Allowable (RDA)is an intake level that meets specified criteria for adequacy, thereby minimizing the risk of nutrient deficiency or excesses. A Maximum Upper Intake Level (UL) is the highest level of daily nutrient intake that is likely to pose no risk of adverse health effects to an individual and represents total intake from food, water, and other supplements (Food and Nutrition Board, 2001; Institute of Medicine, 2001).

Adequate Intake (AI)is the recommended average daily nutrient intake level based on experimentally determined estimates of nutrient intake by groups of apparently healthy people who are assumed to be maintaining an adequate nutritional state. It is expected to meet the needs of most individuals in a specific life-stage and gender group (Institute of Medicine, 2001). The maximum Upper Limit (UL) of Recommended Dietary Allowable (RDA) and Adequate Intake (AI) for the Life Stage Groups of the elements investigated are presented in Table 7.

The estimated Aluminum concentration in salt ranges between $31.3-36.6 \mathrm{mg} / \mathrm{kg}$, giving a mean value of $33.95 \mathrm{mg} / \mathrm{kg}$. Its daily intake in food ranges between 3.4-9.0 mg, giving a mean of $6.2 \mathrm{mg} /$ day (Agency for Toxic Substances and Disease Registry [ATSDR], 2008).Arsenic is a poisonous element(International Agency for Research on Cancer [IARC], 2004; Parker, 2015) but has only recently been classified as an essential nutrient. It, therefore, has no official RDA, but most sources recommend a daily consumption between $0.0125-0.0250 \mathrm{mg}$. Organic arsenic has no tolerable upper limit (UL) and consuming high levels is not thought to be dangerous. Up to $20 \mathrm{mg}$ may be found in the human body to control gene expression, support reproductive health and treat digestive problems (Wilson, 2011).

Lead and Cadmium are extremely toxic and commonly found in industrial workplaces, particularly where ore is processed or smelted. They are also found in some industrial paints, with Cadmium additionally used in the manufacture of certain types of batteries. Investigations have shown that cadmium is an essential trace mineral at very low dosages. There is no RDA established for these two, with no evidence that cadmium undergoes any biotransformation in the human body (In chem, 1990; Occupational Safety and Health Administration [OSHA], 2009).

Many practitioners are hesitant to prescribe oral magnesium preparations due to its known side effect of causing diarrhoea. The recommended daily dose of elemental magnesium is $400 \mathrm{mg}$ per day, with a single dose of 800-1600 mg being necessary to produce a laxative effect (Fine, 1991; Gums, 2004).Food intake is the main source of vanadium with its dietary intake estimated as $0.34 \mu \mathrm{g} / \mathrm{kg}$ and an Upper Tolerable Limit of $1.8 \mathrm{mg} / \mathrm{day}$ (ATSDR, 2012).

Copper is present in organ-meat foods, seafood, nuts, wheat bran cereals, whole grain, and seeds. It is absorbed mainly in the small intestine although some absorption may also occur in the stomach. Absorption varies with copper intake ranging from more than $50 \%$ for intakes below $1 \mathrm{mg}$ /day to less than $20 \%$ for intakes above 5 $\mathrm{mg} /$ day. The very high levels of zinc or iron are taken as supplements generally affects $\mathrm{Cu}$ absorption in the body (Botash et al, 1992; Lonnerdal\&Hernell, 1994; Morais et al, 1994; Turnlund, 1999).

Note:

${ }^{b}$ The UL for magnesium represents intake from a pharmacological agent only and does not include intake from food and water.

${ }^{d}$ Although vanadium in food has not been shown to cause adverse effects in humans, there is no justification for adding it to food. Its supplements should be used with caution. The UL is based on adverse effects in laboratory animals and this data could be used to set a UL for adults but not children or adolescents.

$\mathrm{ND}=$ Not determinable due to lack of data of adverse effects in this age group and concern with regard to lack of ability to handle excess amounts. Source of intake should be from food only to prevent high levels of intake (Food and Nutrition, 2005). 
Table 7: Maximum Upper Limit (UL) of Recommended Dietary Allowable(RDA) and Adequate Intake(AI) for the Life Stage Groups(Food and Nutrition Board, 2001; Institute of Medicine, 2001)

\begin{tabular}{|c|c|c|c|c|c|c|c|c|c|}
\hline \multirow{2}{*}{\multicolumn{2}{|c|}{ Life Stage Group }} & $\mathrm{Al}$ & As & $\mathrm{Cd}$ & $\mathrm{Cu}$ & ${ }^{b} \mathrm{Mg}$ & $\mathrm{Mn}$ & $\mathrm{Pb}$ & ${ }^{d} \mathrm{~V}$ \\
\hline & & $R D A / A I$ & $R D A / A I$ & $R D A / A I$ & $R D A / A I$ & $R D A / A I$ & $A I$ & $R D A / A I$ & $A I$ \\
\hline \multirow[t]{2}{*}{ Infants } & $0-6$ months & ND & ND & ND & ND & ND & ND & ND & ND \\
\hline & $7-12$ months & ND & ND & ND & ND & ND & ND & ND & ND \\
\hline \multirow[t]{2}{*}{ Children } & $1-3 y$ & 0.3 & ND & ND & 1 & 65 & 2 & ND & ND \\
\hline & $4-8 y$ & 0.4 & ND & ND & 3 & 110 & 3 & ND & ND \\
\hline \multirow[t]{6}{*}{ Males } & $9-13 y$ & 0.6 & ND & ND & 5 & 350 & 6 & ND & ND \\
\hline & $14-18 y$ & 0.8 & ND & ND & 8 & 350 & 9 & ND & ND \\
\hline & $19-30 y$ & 1 & ND & ND & 10 & 350 & 9 & ND & 1.8 \\
\hline & $31-50 y$ & 1 & ND & ND & 10 & 350 & 9 & ND & 1.8 \\
\hline & $50-70 y$ & 1 & ND & ND & 10 & 350 & 9 & ND & 1.8 \\
\hline & $>70 y$ & 1 & ND & ND & 10 & 350 & 9 & ND & 1.8 \\
\hline \multirow[t]{6}{*}{ Females } & $9-13 y$ & 0.6 & ND & ND & 5 & 350 & 6 & ND & ND \\
\hline & $14-18 y$ & 0.8 & ND & ND & 8 & 350 & 9 & ND & ND \\
\hline & $19-30 y$ & 1 & ND & ND & 10 & 350 & 9 & ND & 1.8 \\
\hline & $31-50 y$ & 1 & ND & ND & 10 & 350 & 9 & ND & 1.8 \\
\hline & $50-70 y$ & 1 & ND & ND & 10 & 350 & 9 & ND & 1.8 \\
\hline & $>70 y$ & 1 & ND & ND & 10 & 350 & 9 & ND & 1.8 \\
\hline \multirow[t]{6}{*}{ Females } & $9-13 y$ & 0.6 & ND & ND & 5 & 350 & 6 & ND & ND \\
\hline & $14-18 y$ & 0.8 & ND & ND & 8 & 350 & 9 & ND & ND \\
\hline & $19-30 y$ & 1 & ND & ND & 10 & 350 & 9 & ND & 1.8 \\
\hline & $31-50 y$ & 1 & ND & ND & 10 & 350 & 9 & ND & 1.8 \\
\hline & $50-70 y$ & 1 & ND & ND & 10 & 350 & 9 & ND & 1.8 \\
\hline & $>70 y$ & 1 & ND & ND & 10 & 350 & 9 & ND & 1.8 \\
\hline \multirow{3}{*}{$\begin{array}{l}\text { Pregnant } \\
\text { Women }\end{array}$} & $\leq \quad 18 \mathrm{y}$ & 0.8 & ND & ND & 8 & 350 & 9 & ND & ND \\
\hline & $19-30 y$ & 1 & ND & ND & 10 & 350 & 11 & ND & ND \\
\hline & $31-50 y$ & 1 & ND & ND & 10 & 350 & 11 & ND & ND \\
\hline \multirow{3}{*}{$\begin{array}{l}\text { Lactation } \\
\text { Women }\end{array}$} & $18 \mathrm{y}$ & 0.8 & ND & ND & 8 & 350 & 9 & ND & ND \\
\hline & $19-30 y$ & 1 & ND & ND & 10 & 350 & 11 & ND & ND \\
\hline & $31-50 y$ & 1 & ND & ND & 10 & 350 & 11 & ND & ND \\
\hline
\end{tabular}

4.7 Calculating the Daily Average Intake based on Dietary Reference

Considering an average daily salt intake of $6,000 \mathrm{mg}$, the daily average intake of the elements when one consumes salt mined from the Benya lagoon was calculated using Pourgheysari formula presented in equation (3) (Pourgheysari et al., 2012; Mahan \& Escott-Stump, 2008; Ireland et al., 2010). Results obtained are presented in Table 8.

Daily Intake of Heavy Metals $=$ COHMITS $\times$ MSIGPD

where COHMITS is the concentration of metal impurities in the salt and MSIGPD is the mean salt intake (g/person/day) 
Table 8: Calculated mean daily intake of the elements

\begin{tabular}{|c|c|c|}
\hline & $\begin{array}{c}\text { Mean Concentration of } \\
\text { Elements (mg/kg) }\end{array}$ & $\begin{array}{c}\text { Calculated Mean Daily } \\
\text { Intake (mg/day) }\end{array}$ \\
\hline $\mathrm{Al}$ & 355.74 & 2134.44 \\
\hline $\mathrm{As}$ & 0.0016 & 0.012 \\
\hline $\mathrm{Cd}$ & 0.001 & 0.006 \\
\hline $\mathrm{Cu}$ & 1.848 & 11.1 \\
\hline $\mathrm{Mg}$ & 2431.428 & 14588.58 \\
\hline $\mathrm{Mn}$ & 39.54 & 237.24 \\
\hline $\mathrm{Pb}$ & 0.001 & 0.006 \\
\hline $\mathrm{V}$ & 4.788 & 28.74 \\
\hline
\end{tabular}

Values in Table 8 were compared to the Maximum Upper Limit (UL) of Recommended Dietary Allowable (RDA) and Adequate Intake(AI) for the Life Stage Groups (Table 7) and the difference in values presented in Table 9. It will realize that all the calculated values in Table 9 are above each element's Upper Tolerable Limit of its RDA. The positive sign (+) denotes that the values are above the ULs. To determine its effect on the health of a consumer the Health Risk was estimated by calculating the Hazard Index (HI).

Table 9: Differences between the UL of the RDA / AI and the Calculated Means for the Life Stage Groups

\begin{tabular}{|c|c|c|c|c|c|c|c|c|c|}
\hline \multicolumn{2}{|c|}{ Life Stage Group } & \multirow{2}{*}{$\begin{array}{c}\begin{array}{c}\mathrm{Al} \\
(\mathrm{mg} / \mathrm{d})\end{array} \\
\mathrm{ND} \\
\mathrm{ND}\end{array}$} & \multirow{2}{*}{$\begin{array}{c}\begin{array}{c}\mathrm{As} \\
(\mathrm{mg} / \mathrm{d})\end{array} \\
\mathrm{ND} \\
\mathrm{ND}\end{array}$} & \multirow{2}{*}{$\begin{array}{c}\begin{array}{c}\mathrm{Cd} \\
(\mathrm{mg} / \mathrm{d})\end{array} \\
\mathrm{ND} \\
\mathrm{ND}\end{array}$} & \multirow{2}{*}{$\begin{array}{c}\begin{array}{c}\mathrm{Cu} \\
(\mathrm{mg} / \mathrm{d})\end{array} \\
\mathrm{ND} \\
\mathrm{ND}\end{array}$} & \multirow{2}{*}{$\begin{array}{c}\begin{array}{c}\mathrm{Mg} \\
(\mathrm{mg} / \mathrm{d})\end{array} \\
\mathrm{ND} \\
\mathrm{ND}\end{array}$} & \multirow{2}{*}{$\begin{array}{c}\begin{array}{c}\mathrm{Mn} \\
(\mathrm{mg} / \mathrm{d})\end{array} \\
\mathrm{ND} \\
\mathrm{ND}\end{array}$} & \multirow{2}{*}{$\begin{array}{c}\begin{array}{c}\mathrm{Pb} \\
(\mathrm{mg} / \mathrm{d})\end{array} \\
\mathrm{ND} \\
\mathrm{ND}\end{array}$} & \multirow{2}{*}{$\begin{array}{c}\begin{array}{c}\mathrm{V} \\
(\mathrm{mg} / \mathrm{d})\end{array} \\
\mathrm{ND} \\
\mathrm{ND}\end{array}$} \\
\hline Infants & $\begin{array}{l}0-6 \text { months } \\
7-12 \text { months }\end{array}$ & & & & & & & & \\
\hline Children & $\begin{array}{l}1-3 y \\
4-8 y\end{array}$ & $\begin{array}{l}+2134.14 \\
+2134.04\end{array}$ & $\begin{array}{l}\text { ND } \\
\text { ND }\end{array}$ & $\begin{array}{l}\text { ND } \\
\text { ND }\end{array}$ & $\begin{array}{l}+10.1 \\
+8.1\end{array}$ & $\begin{array}{l}+14523.58 \\
+14488.58\end{array}$ & $\begin{array}{l}+235.24 \\
+234.24\end{array}$ & $\begin{array}{l}\text { ND } \\
\text { ND }\end{array}$ & $\begin{array}{l}\text { ND } \\
\text { ND }\end{array}$ \\
\hline Males & $\begin{array}{l}9-13 \mathrm{y} \\
14-18 \mathrm{y} \\
19-30 \mathrm{y} \\
31-50 \mathrm{y} \\
50-70 \mathrm{y} \\
>70 \mathrm{y}\end{array}$ & $\begin{array}{l}+2133.84 \\
+2133.64 \\
+2133.44 \\
+2133.44 \\
+2133.44 \\
+2133.44\end{array}$ & $\begin{array}{l}\text { ND } \\
\text { ND } \\
\text { ND } \\
\text { ND } \\
\text { ND } \\
\text { ND }\end{array}$ & $\begin{array}{l}\text { ND } \\
\text { ND } \\
\text { ND } \\
\text { ND } \\
\text { ND } \\
\text { ND }\end{array}$ & $\begin{array}{l}+6.1 \\
+3.1 \\
+1.1 \\
+1.1 \\
+1.1 \\
+1.1\end{array}$ & $\begin{array}{l}+14238.58 \\
+14238.58 \\
+14238.58 \\
+14238.58 \\
+14238.58 \\
+14238.58\end{array}$ & $\begin{array}{l}+231.24 \\
+228.24 \\
+228.24 \\
+228.24 \\
+228.24 \\
+228.24\end{array}$ & $\begin{array}{l}\text { ND } \\
\text { ND } \\
\text { ND } \\
\text { ND } \\
\text { ND } \\
\text { ND }\end{array}$ & $\begin{array}{c}\mathrm{ND} \\
\mathrm{ND} \\
+26.94 \\
+26.94 \\
+26.94 \\
+26.94\end{array}$ \\
\hline Females & $\begin{array}{l}9-13 y \\
14-18 y \\
19-30 y \\
31-50 y \\
50-70 y \\
>70 y\end{array}$ & $\begin{array}{l}+2133.84 \\
+2133.64 \\
+2133.44 \\
+2133.44 \\
+2133.44 \\
+2133.44\end{array}$ & $\begin{array}{l}\text { ND } \\
\text { ND } \\
\text { ND } \\
\text { ND } \\
\text { ND } \\
\text { ND }\end{array}$ & $\begin{array}{l}\text { ND } \\
\text { ND } \\
\text { ND } \\
\text { ND } \\
\text { ND } \\
\text { ND }\end{array}$ & $\begin{array}{l}+6.1 \\
+3.1 \\
+1.1 \\
+1.1 \\
+1.1 \\
+1.1\end{array}$ & $\begin{array}{l}+14238.58 \\
+14238.58 \\
+14238.58 \\
+14238.58 \\
+14238.58 \\
+14238.58\end{array}$ & $\begin{array}{l}+231.24 \\
+228.24 \\
+228.24 \\
+228.24 \\
+228.24 \\
+228.24\end{array}$ & $\begin{array}{l}\text { ND } \\
\text { ND } \\
\text { ND } \\
\text { ND } \\
\text { ND } \\
\text { ND }\end{array}$ & $\begin{aligned} & \mathrm{ND} \\
& \mathrm{ND} \\
&+26.94 \\
&+26.94 \\
&+26.94 \\
&+26.94\end{aligned}$ \\
\hline $\begin{array}{l}\text { Pregnant } \\
\text { Women }\end{array}$ & $\begin{array}{l}\leq \quad 18 \mathrm{y} \\
19-30 \mathrm{y} \\
31-50 \mathrm{y}\end{array}$ & $\begin{array}{r}+2133.64 \\
+2133.44 \\
+2133.44\end{array}$ & $\begin{array}{l}\text { ND } \\
\text { ND } \\
\text { ND }\end{array}$ & $\begin{array}{l}\text { ND } \\
\text { ND } \\
\text { ND }\end{array}$ & $\begin{array}{l}+3.1 \\
+1.1 \\
+1.1\end{array}$ & $\begin{array}{l}+14238.58 \\
+14238.58 \\
+14238.58\end{array}$ & $\begin{array}{l}+228.24 \\
+226.24 \\
+226.24\end{array}$ & $\begin{array}{l}\text { ND } \\
\text { ND } \\
\text { ND }\end{array}$ & $\begin{array}{l}\text { ND } \\
\text { ND } \\
\text { ND }\end{array}$ \\
\hline $\begin{array}{l}\text { Lactation } \\
\text { Women }\end{array}$ & $\begin{array}{l}\leq \quad 18 \mathrm{y} \\
19-30 \mathrm{y} \\
31-50 \mathrm{y}\end{array}$ & $\begin{array}{l}+2133.64 \\
+2133.44 \\
+2133.44\end{array}$ & $\begin{array}{l}\text { ND } \\
\text { ND } \\
\text { ND }\end{array}$ & $\begin{array}{l}\text { ND } \\
\text { ND } \\
\text { ND }\end{array}$ & $\begin{array}{l}+3.1 \\
+1.1 \\
+1.1\end{array}$ & $\begin{array}{l}+14238.58 \\
+14238.58 \\
+14238.58\end{array}$ & $\begin{array}{l}+228.24 \\
+226.24 \\
+226.24\end{array}$ & $\begin{array}{l}\text { ND } \\
\text { ND } \\
\text { ND }\end{array}$ & $\begin{array}{l}\text { ND } \\
\text { ND } \\
\text { ND }\end{array}$ \\
\hline
\end{tabular}

\subsection{Assessment According to Health Risk Estimation}

The Hazard Index is calculated by comparing the estimated dose (ED) to the Reference Dose RfD (an estimate of a daily consumption level that is likely to be without deleterious effects in a lifetime). It is defined by equation (4) (Laar et al, 2011) as: 


$$
\text { The hazard index }(\mathrm{HI})=\frac{\mathrm{ED}}{\mathrm{RfD}} \text {, }
$$

$\mathrm{HI}<1$ suggests an unlikely adverse health effect whereas $\mathrm{HI}>1$ suggests the probability of adverse health effects (Laar et al, 2011). The calculated HI which estimates the health risk associated with the consumption of the salt is presented in Table 10. It will be seen that apart from the sections that could not be determined due to lack of data (ND) all the calculated values were $>1$, suggesting the probability of adverse effects.

Table 10: Health Risk Estimates Associated with the Eating of Table Salt mined from Benya lagoon for the Life Stage Groups

\begin{tabular}{|c|c|c|c|c|c|c|c|c|c|}
\hline \multirow{2}{*}{\multicolumn{2}{|c|}{ Life Stage Group }} & \multicolumn{8}{|c|}{ Hazard Index } \\
\hline & & \multirow{3}{*}{$\begin{array}{l}\mathrm{Al} \\
\mathrm{ND} \\
\mathrm{ND}\end{array}$} & \multirow{3}{*}{$\begin{array}{c}\text { As } \\
\text { ND } \\
\text { ND }\end{array}$} & \multirow{3}{*}{$\begin{array}{c}\mathrm{Cd} \\
\mathrm{ND} \\
\mathrm{ND}\end{array}$} & \multirow{3}{*}{$\begin{array}{c}\mathrm{Cu} \\
\mathrm{ND} \\
\mathrm{ND}\end{array}$} & \multirow{3}{*}{$\begin{array}{l}\mathrm{Mg} \\
\mathrm{ND} \\
\mathrm{ND}\end{array}$} & \multirow{3}{*}{$\begin{array}{l}\text { Mn } \\
\text { ND } \\
\text { ND }\end{array}$} & \multirow{3}{*}{$\begin{array}{l}\mathrm{Pb} \\
\mathrm{ND} \\
\mathrm{ND}\end{array}$} & \multirow{3}{*}{$\begin{array}{c}\mathrm{V} \\
\mathrm{ND} \\
\mathrm{ND}\end{array}$} \\
\hline Infants & $0-6$ months & & & & & & & & \\
\hline & 7-12months & & & & & & & & \\
\hline \multirow[t]{2}{*}{ Children } & $1-3 y$ & 7114.80 & ND & ND & 11.1 & 224.44 & 118.62 & ND & ND \\
\hline & $4-8 y$ & 5336.10 & ND & ND & 3.7 & 132.62 & 79.08 & ND & ND \\
\hline \multirow[t]{6}{*}{ Males } & $9-13 y$ & 3557.40 & ND & ND & 2.22 & 41.48 & 39.54 & ND & ND \\
\hline & $14-18 y$ & 2668.05 & ND & ND & 1.39 & 41.68 & 26.36 & ND & ND \\
\hline & $19-30 y$ & 2134.44 & ND & ND & 1.11 & 41.68 & 26.36 & ND & 15.97 \\
\hline & $31-50 y$ & 2134.44 & ND & ND & 1.11 & 41.48 & 26.36 & ND & 15.97 \\
\hline & $50-70 y$ & 2134.44 & ND & ND & 1.11 & 41.68 & 26.36 & ND & 15.97 \\
\hline & $>70 y$ & 2134.44 & ND & ND & 1.11 & 41.68 & 26.36 & ND & 15.97 \\
\hline \multirow[t]{6}{*}{ Females } & $9-13 y$ & 3557.40 & ND & ND & 2.22 & 41.48 & 39.54 & ND & ND \\
\hline & $14-18 y$ & 2668.05 & ND & ND & 1.39 & 41.68 & 26.36 & ND & ND \\
\hline & $19-30 y$ & 2134.44 & ND & ND & 1.11 & 41.68 & 26.36 & ND & 15.97 \\
\hline & $31-50 y$ & 2134.44 & ND & ND & 1.11 & 41.48 & 26.36 & ND & 15.97 \\
\hline & $50-70 y$ & 2134.44 & ND & ND & 1.11 & 41.68 & 26.36 & ND & 15.97 \\
\hline & $>70 y$ & 2134.44 & ND & ND & 1.11 & 41.68 & 26.36 & ND & 15.97 \\
\hline \multirow{3}{*}{$\begin{array}{l}\text { Pregnant } \\
\text { Women }\end{array}$} & $18 \mathrm{y}$ & 2668.05 & ND & ND & 1.39 & 41.48 & 26.36 & ND & ND \\
\hline & $19-30 y$ & 2134.44 & ND & ND & 1.11 & 41.68 & 21.57 & ND & ND \\
\hline & $31-50 y$ & 2134.44 & ND & ND & 1.11 & 41.68 & 21.57 & ND & ND \\
\hline \multirow{3}{*}{$\begin{array}{l}\text { Lactation } \\
\text { Women }\end{array}$} & $18 \mathrm{y}$ & 2668.05 & ND & ND & 1.39 & 41.48 & 26.36 & ND & ND \\
\hline & $19-30 y$ & 2134.44 & ND & ND & 1.11 & 41.68 & 21.57 & ND & ND \\
\hline & $31-50 y$ & 2134.44 & ND & ND & 1.11 & 41.68 & 21.57 & ND & ND \\
\hline
\end{tabular}

The elements investigated are essential to human health but can be toxic at concentrations higher than that necessary for the biological functions of the growth processes. Table 11 lists the some functions of the elements in the human body and their effects when consumed in deficient or excessive amounts. 
Table 11: Some Functions and Effects of the metal impurities on the Human Body

\begin{tabular}{|c|c|c|c|}
\hline Element & Function & Adverse Effect of Deficiency & Adverse Effect of Excessive Consumption \\
\hline \multirow[t]{2}{*}{$\mathrm{Al}$} & $\begin{array}{l}\text { Increases the body's } \\
\text { immune response }\end{array}$ & $\begin{array}{l}\text { Neuro-toxic effects, effects on } \\
\text { bone and reproduction. }\end{array}$ & Seizures, coma, aluminium bone disease \\
\hline & \multicolumn{3}{|l|}{ (Family Supplement, 2009) } \\
\hline \multirow[t]{2}{*}{ As } & $\begin{array}{l}\text { Controls gene expression, } \\
\text { supports reproductive } \\
\text { health and treats digestive } \\
\text { problems }\end{array}$ & $\begin{array}{l}\text { Abnormal growth, problems } \\
\text { with heart and bones. }\end{array}$ & $\begin{array}{l}\text { Risk of cancer in the liver, bladder, kidneys, } \\
\text { prostate, and lungs, inflammation of the } \\
\text { skin. Causes anaemia, depression, } \\
\text { gastrointestinal problems and even death }\end{array}$ \\
\hline & \multicolumn{3}{|l|}{ ([IARC], 2004; Parker, 2015). } \\
\hline \multirow[t]{2}{*}{$\mathrm{Cd}$} & ND & ND & $\begin{array}{l}\text { Diarrhoea, Nausea, Excessive salivation, } \\
\text { Abdominal pain, Increased bone fractures, } \\
\text { Low back pain, Chest pain, anaemia, } \\
\text { hypertension, and hepatitis }\end{array}$ \\
\hline & \multicolumn{3}{|c|}{ (Mcguigan, 2011; ATSDR, 2011) } \\
\hline \multirow[t]{2}{*}{$\mathrm{Cu}$} & $\begin{array}{l}\text { Fixes calcium in the bones } \\
\text { and to build and repair all } \\
\text { connective tissue (skin, } \\
\text { tendons, ligaments, } \\
\text { arteries, veins, hair, nails,). }\end{array}$ & $\begin{array}{l}\text { Low libido in women and. } \\
\text { Increases the lipid } \\
\text { peroxidation in the heart in 2- } \\
\text { folds. }\end{array}$ & $\begin{array}{l}\text { Vomiting, nausea, abdominal pain, } \\
\text { weakness, Menstrual cramps, and metallic } \\
\text { taste in the mouth. Liver and kidney } \\
\text { damage. }\end{array}$ \\
\hline & \multicolumn{3}{|l|}{ (Nolan, 1983) } \\
\hline \multirow[t]{2}{*}{$\mathrm{Mg}$} & $\begin{array}{l}\text { Maintains normal nerve and } \\
\text { muscle function, supports a } \\
\text { healthy immune system, } \\
\text { keeps the heart beat steady, } \\
\text { and helps bones remain } \\
\text { strong. Helps regulate blood } \\
\text { glucose levels and aids in } \\
\text { the production of energy } \\
\text { and protein. }\end{array}$ & $\begin{array}{l}\text { Anorexia, Apathy, Fatigue, } \\
\text { Confusion, Insomnia, Poor } \\
\text { memory, Muscle twitching, } \\
\text { Irritability, Reduced ability } \\
\text { to learn, Hallucinations, } \\
\text { Rapid heartbeat, Continued } \\
\text { muscle contraction, } \\
\text { Numbness, Delirium, }\end{array}$ & $\begin{array}{l}\text { Gastrointestinal: diarrhoea, stomach upset, } \\
\text { nausea, vomiting and abdominal cramping. } \\
\text { Affects the cardiovascular system, muscle } \\
\text { weakness and difficulty in breathing. } \\
\text { Changes in mental status, affects the } \\
\text { balance of other minerals in the body, }\end{array}$ \\
\hline & \multicolumn{3}{|c|}{ (Busse, 2015; National Health and Medical Research Council [NHRMC], 2015) } \\
\hline \multirow[t]{2}{*}{ Mn } & $\begin{array}{l}\text { Helps bone formation and } \\
\text { the action of some } \\
\text { enzymes such as those } \\
\text { involved in carbohydrate } \\
\text { metabolism }\end{array}$ & $\begin{array}{l}\text { Obesity, birth defects, changes } \\
\text { of hair colour, abnormal bone } \\
\text { function and cartilage, growth } \\
\text { retardation. }\end{array}$ & $\begin{array}{l}\text { Neurotoxicity and elevated blood } \\
\text { concentration, high incidence of pneumonia } \\
\text { and other upper respiratory infections }\end{array}$ \\
\hline & \multicolumn{3}{|l|}{ (Lenntech, 2018) } \\
\hline \multirow[t]{2}{*}{$\mathrm{Pb}$} & ND & ND & $\begin{array}{l}\text { Abdominal cramps and pain, fatigue, } \\
\text { aggressive behaviour, constipation, sleep } \\
\text { problems, headaches, irritability, loss of } \\
\text { developmental skills in children, loss of } \\
\text { appetite, high blood pressure, numbness or } \\
\text { tingling in the extremities, memory loss, } \\
\text { anemia, kidney dysfunction }\end{array}$ \\
\hline & \multicolumn{3}{|l|}{ (Healthline, 2019) } \\
\hline \multirow[t]{2}{*}{$\mathrm{V}$} & $\begin{array}{lcr}\text { Controls } & \text { blood } & \text { sugar } \\
\text { levels, } & \text { retards } & \text { tumor } \\
\text { growth. } & & \\
\end{array}$ & $\begin{array}{l}\text { Kidney and heart disease, low } \\
\text { blood sugar levels. }\end{array}$ & $\begin{array}{l}\text { Elevation in blood pressure, abdominal } \\
\text { cramps, diarrhoea. }\end{array}$ \\
\hline & \multicolumn{3}{|c|}{ (Murray, 2005; Tracey et al., 2007) } \\
\hline
\end{tabular}

\section{Conclusion}

This study determined the wholesomeness of salt mined from the Benya Lagoon (located in Elmina, the Central Region of Ghana) by testing for the presence and concentration of metal impurities Arsenic (As), Cadmium (Cd), Manganese ( $\mathrm{Mn}$ ) Lead ( $\mathrm{Pb})$, Aluminium ( $\mathrm{Al}$ ), Copper $(\mathrm{Cu})$, Magnesium (Mg), and Vanadium (V). The salt was produced from salty water pumped from the lagoon into manmade ponds and evaporated using natural energy from the sun. Five (5) of such ponds (stations 1-5) were used in this study and Neutron Activation Analysis technique used to determine the concentration of the metal impurities. 
A Principal Component Biplot which combines the scores and loadings in one plot was used to depict the relationships between the stations (observations) and how each of the metal impurities (variables) measured from the salts contributed to the variations or similarities among the stations. This analysis made it possible to trace the particular station where salt was mined based on the measured levels of metal impurity. It also made it possible to relate the activity that goes on around a particular station based on the concentrations of the metal impurities measured.

Pearson's correlation coefficient was used to draw parallels between any two of the metal impurities. Significant correlations were drawn between $\mathrm{Al}$ and $\mathrm{Mg}(\mathrm{r}=-0.862), \mathrm{Mg}$ and $\mathrm{Mn}(\mathrm{r}=0.863)$ and $\mathrm{Mn}$ and $\mathrm{V}(\mathrm{r}=$ $0.735)$, indicating the same or similar source inputs for each pair.

Various assessments were carried out to determine the extent of metal impurity contamination. An assessment according to Codex Standard for Food Grade Salt showed that concentration values for $\mathrm{Al}, \mathrm{Mg}$, and $\mathrm{Mn}$ were above the recommended limits. This was confirmed by the contamination factor $\left(\mathrm{C}_{\mathrm{F}}\right)$ and degree of contamination $\left(\mathrm{C}_{\mathrm{D}}\right)$ which recorded very high levels of contamination for $\mathrm{Al}, \mathrm{Mg}$, and $\mathrm{Mn}$ for all five Stations, with Station 2 recording the highest Degree of Contamination.

An assessment according to metal impurity concentration confirmed $\mathrm{Mg}$ as the most abundant, $[\mathrm{Cd}]=[\mathrm{Pb}]$ the least and again salt mined from station 2 having the highest concentration considering the combined toxicity of all the metal impurities at each station. Salt from station 5 recorded the least concentration.

Considering an average daily salt intake of $6,000 \mathrm{mg}$, the mean daily intake of the elements when one consumes salt mined from the Benya lagoon was calculated and values obtained compared with the Maximum Upper Limit (UL) of Recommended Dietary Allowable (RDA) and Adequate Intake (AI) for the various Life Stage Groups. The calculated values were found to be above each element's Upper Tolerable Limit of its Recommended Dietary Allowable. The health risk associated when the Hazard Index was calculated suggested the probability of adverse effects. High standard deviation values obtained for $\mathrm{Mg}, \mathrm{Al}$ and $\mathrm{Mn}$ indicated the non-uniform spatial distribution of the individual metal contaminates at the various sampling stations.

Contamination of the Lagoon is true as a result of anthropogenic activities such as the unregulated disposal of refuse, the inflow of lingering chemicals from farms, exposure of treated wood meant for boat construction and the practice of attaching lead-ingots to nets to act as 'sinks' during fishing. Most importantly it is contaminated due to the activities of auto-mechanics who have their shops located along the banks of the lagoon and casually dispose off their damaged car parts and used car batteries along the banks of the lagoon. The contamination of the lagoon will persist so long as such unhealthy practices and activities continue. Proper education and dredging of the lagoon to rid it of the solid wastes will go a long way in mitigating the extent of pollution and consequently improve the quality of salt mined using water from the lagoon.

\section{LAFOC Research Group}

Some of the authors, as indicated in the addresses, belong to the Laser and Fibre Optics Centre (LAFOC) research group of the University of Cape Coast, Cape Coast, Ghana.

\section{Acknowledgment}

The authors wish to express their sincere appreciation to the technicians and staff of Ghana Atomic Energy Commission at Kwabenya - Accra, for their kind assistance in the analysis of the samples.

\section{References}

Agency for Toxic Substances and Disease Registry [ATSDR].(2008). Toxicological profile for Aluminium. Atlanta, GA: U.S. Department of Health and Human Services, Public Health Service.

Al-Busaidi, M., Yesudhason, P., Al-Mughairi, S., Al-Rahbi, W.A.K., Al-Harthy, K.S. \& Al-Mazrooei, N. A. (2011). Toxic metals in commercial marine fish in Oman with reference to national and international standards.Chemosphere, 85 (1), pp. 67-73

ATSDR. (2011). Cadmium Toxicity. Case Studies in Environmental Medicine (CSEM) Cadmium Toxicity. Retrieved from https://www.atsdr.cdc.gov/csem/cadmium/docs/cadmium.pdf, Assessed on 28-02-2019

ATSDR.(2012). Toxicological profile for Vanadium. Atlanta, GA: U.S. Department of Health and Human Services, Public Health Service.

Alfassi, Z.B. (1994). Chemical Analysis by Nuclear Methods.John Wiley and Sons. 
Amorim, F. A., \& Ferreira, S. L. (2005).Determination of cadmium and lead in table salt by sequential multi-element flame atomic absorption spectrometry.Talanta, 65(4), 960-964.

Armah F. A., Yawson D. O., Alex N. M., Pappoe N.M., and Afrifa E. K. A. (2010). Participation and Sustainable Management of Coastal Lagoon Ecosystems: The Case of the Fosu Lagoon in Ghana, Sustainability, 2, 383-399

Boppel, B. (1976). Lead-and cadmium-content of foodstuffs 1. Lead-and Cadmium-content of spices and table salt (author's transl). Zeitschrift Fur Lebensmittel-Untersuchung Und-Forschung, 160(3), 299-302.

Botash, A. S., Nasca, J., Dubowy, R., Weinberger, H. L., \& Oliphant, M. (1992). Zinc-induced copper deficiency in an infant. American Journal of Diseases of Children, 146(6), 709-711.

Bro, R. \&Smilde, A. K. (2014).Principal component analysis, Anal. Methods, 2014, (6), 2812

Busse M., (2015). Signs and Symptoms of Too Much Magnesium. Retrieved from http://www.livestrong.com/article/379016-signs-and-symptoms-of-too-much-magnesium/, Assessed on 28-022019.

Canli M. \&Atli G. (2003). The relationships between heavy metal (Cd, Cr, Cu, Fe, Pb, $\mathrm{Zn}$ ) levels and the size of six Mediterranean fish species. Environ Pollut. 2003; 121(1):129-36.

Cheraghali, A. M., Kobarfard, F., \&Faeizy, N. (2010).Heavy metals contamination of table salt consumed in Iran.Iranian journal of pharmaceutical research: IJPR, 9(2), 129.

Codex.(2006). CODEX STAN 150-1985 Standard for Food Grade Salt. Retrieved from http://files.foodmate.com/2013/files_1116.html, Assessed on 18-06-2015

Currie, L. A. (1991).The importance of chemometrics in biomedical measurements. In: K. S.

Subramamanian, K. Okamoto, \& G.V. Iyengar (Eds.), Biomedical Trace Element Research: American College of Surgeons Symposium Series (pp. 72 - 100). Washington, DC: American Chemical Society

Electrical4u. (2015). Magnesium Battery Chemistry Construction of Magnesium Battery. Retrieved from http://www.electrical4u.com/magnesium-battery-chemistry-construction-of-magnesiu m-battery/, Assessed on 28-02-2019

Family supplement. (2009). What is the Role of Aluminium in Good Nutrition? Retrieved from http://www.family-supplement-selection-guide.com/Aluminium.html/, Assessed on 28-02-2019.

Fine, K. D., Santa Ana, C. A., Porter, J. L., \&Fordtran, J. S. (1991). Intestinal absorption of magnesium from food and supplements.The Journal of clinical investigation, 88(2), 396-402.

Food and Nutrition.(2005). Dietary Reference Intakes, Health Canada. Retrieved from http://www.hc-sc.gc.ca/fn-an/nutrition/reference/table/ref_elements_tbleng.php

Food and Nutrition Board.(2001). Intake Applications in Dietary Assessment.Washington, DC: National Academy Press.

GIS, (2012).The Department of Geography and Regional Planning: University of Cape Coast, Cape Coast.

Gums, J. G. (2004).Magnesium in cardiovascular and other disorders.American journal of health-system pharmacy, 61(15), 1569-1576.

Healthline. (2019). Lead poisoning. Retrieved from http://www.healthline.com/health/lead-poiso ning\#Overview1, Assessed on 28-02-2019

International Agency for Research on Cancer [IARC]. (2004). Arsenic and Arsenic Compounds (Monograph), 2002, 1-484. Retrieved from http://monographs.iarc.fr/ENG/Mon 
ographs/vol100C/mono100C-6.pdf, Assessed on 28-02-2019

INCHEM.(1990). Cadmium (PIM 089). Retrieved from http://www.inchem.org/documents/pi $\mathrm{ms} / \mathrm{chemical} / \mathrm{cadmium} . \mathrm{html}$, Assessed on 28-02-2019

Institute of Medicine (2001).Dietary Reference Intakes for Vitamin A, Vitamin K, Arsenic, Boron, Chromium, Copper, Iodine, Iron, Manganese, Molybdenum, Nickel, Silicon, Vanadium, and Zinc. Washington, DC: The National Academies Press

Ireland, D. M., Clifton, P. M., \& Keogh, J. B. (2010).Achieving the salt intake target of $6 \mathrm{~g} /$ day in the current food supply in free-living adults using two dietary education strategies.Journal of the American Dietetic Association, 110(5), 763-767.

Kelly, R. P., \& Moran, S. B. (2002). Seasonal changes in groundwater input to a well-mixed estuary estimated using radium isotopes and implications for coastal nutrient budgets. Limnology and Oceanography, 47(6), 1796-1807.

Laar, C., Fianko, J. R., Akiti, T. T., Osae, S., \&Brimah, A. K. (2011). Determination of heavy metals in the blackchin tilapia from the Sakumo Lagoon, Ghana.Research Journal of Environmental and Earth Sciences, 3(1), 8-13.

Lenntech.(2018). Manganese. Retrieved from https://www.lenntech.com/periodic/elements/mn.htm\#ixzz1Yo2PyN00, Assessed on 12-04-2018

Lönnerdal, B.,\&Hernell, O. (1994). Iron, zinc, copper and selenium status of breast-fed infants and infants fed trace element fortified milk-based infant formula. ActaPaediatrica, 83(4), 367-373.

Loux, R. (2006). The Balanced Plate: The Essential Elements of Whole Foods and Good Health. New York, NY: Rodale.

Mahan, L. K., \&Escott-Stump, S. (2008). Krause's food and nutrition therapy (11th ed.). Philadelphia, USA: Elsevier Saunders. 900-916.

Mahurpawar M., (2015). Effects of Heavy Metals on Human Health, International Journal of Research -Granthaalaah, Retrieved from http://granthaalayah.com/Articles/Vol3Iss9SE/152_IJRG15_S 09_152.pdf, Assessed on 28-02-2019

Maldon Salt. (2014). Salt an amazing history. Retrieved from http://www.maldonsalt.co.uk/About-Salt-Salt-an-amazing-history.html, Assessed on 28-02-2019

Martin, J. M., \&Meybeck, M. (1979).Elemental mass-balance of material carried by major world rivers.Marine chemistry, 7(3), 173-206.

Mcguigan, M. A. (2011). Chronic poisoning: trace metals and others. In L. Goldman, \& A. I. Schafer (Eds.), Goldman's Cecil Medicine (pp.88 -98). Philadelphia, PA: Elsevier Saunders.

Merriam-Webster Medical Dictionary.(2015). Dietary Reference Intake. Retrieved from http://www.merriam-webster.com/medical/dietary\%20reference\%20intake, Assessed on 28-02-2019

Morais, M. B., Fisberg, M., Suzuki, H. U., Amancio, O. M. S., \& Machado, N. L. (1994).Effects of oral iron therapy on serum copper and serum ceruloplasmin in children.Journal of tropical pediatrics, 40(1), 51-52.

Murray, M. T. (2005). Encyclopaedia of Nutritional Supplements, the Essential Guide for Improving Your Health Naturally. Roseville, California: Prima Publishing.

Musaiger, A. O., Al-Jedah, J. H., \&D'souza, R. (2008).Occurrence of contaminants in foods commonly consumed in Bahrain.Food Control, 19(9), 854-861.

National Health and Medical Research Council [NHRMC]. (2015). Magnesium in diet: MedlinePlus Medical Encyclopedia. Retrieved from https://www.nlm.nih.gov/medlineplus/ency/article/002423.htm, 
Assessed on 28-02-2019

Nnorom, I. C., Osibanjo, O., \&Ogugua, K. (2007). Trace heavy metal levels of some bouillon cubes, and food condiments readily consumed in Nigeria. Pakistan Journal of Nutrition, 6(2), 122-127.

Nolan, K. R. (1983). Copper toxicity syndrome. Journal of Orthomolecular Psychiatry, 12(4), 270-282.

Occupational Safety and Health Administration [OSHA]. (2009). Safety and Health Topics: Cadmium. Retrieved from http://www.osha.gov/SLTC/cadmium/index.html, Assessed on 28-02-2019

Oria, M., Yaktine, A. L., \& Strom, B. L. (Eds.). (2013). Sodium intake in populations: assessment of evidence. National Academies Press.

Pallant, J. (2007). SPSS Survival Manual: A Step to Step Guide to Data Analysis using SPSS for Windows. (3rd Edition).Open University Press, New York, USA.Pp 132-133

Parker, T. (2015).Arsenic - An Essential Nutrient for Growth. Retrieved from http://www.articlesnatch.com/Article/Arsenic---An-Essential-Nutrient-For-Growth/1948700, Assessed on 28-022019

Pourgheysari, H., Moazeni, M., \&Ebrahimi, A. (2012).Heavy metal content in edible salts in Isfahan and estimation of their daily intake via salt consumption.International Journal of Environmental Health Engineering, $1(1), 8$

Rahman, M. S., Molla, A. H., Saha, N. \&Rahman, A. (2012).Study on heavy metals levels and its risk assessment in some edible fishes from Bangshi River, Savar, Dhaka, Bangladesh. Food Chem, 134 (4) (2012), pp. 1847-1854

Royal Society of Chemistry [RSC], (2015).Magnesium, Uses and Properties. Retrieved from http://www.rsc.org/periodic-table/element/12/magnesium, Assessed on 28-02-2019

Rumsey, J.D. (2010). Statistics for Dummies, Wiley Publishing, Inc., USA.pg 117.

Schmermer F., (2011) Silt and dirt chokesFosu Lagoon, Central Press.

http://centralpressnewspaper.blogspot.com/, Assessed on 27-09-2013

Soylak, M., Peker, D. S. K., \&Turkoglu, O. (2008). Heavy metal contents of refined and unrefined table salts from Turkey, Egypt and Greece. Environmental monitoring and assessment, 143(1-3), 267-272.

SRP Dartmouth Toxic Metals, (2018).Review of the Drinking Water Maximum Contaminant Level (MCL), Retrieved fromhttps://www.dartmouth.edu/ toxmetal/news-events/index.html, Assessed on 28-02-2019

Tandoh, J. B., Bredwa-Mensah, Y., Dampare, S. B., Akaho, E. H. K., \&Nyarko, B. J. B. (2009). Chemical characterization of ancient pottery from the greater Accra region of Ghana using neutron activation analysis.Nuclear Instruments and Methods in Physics Research Section B: Beam Interactions with Materials and Atoms, 267(11), 1924-1930.

Tracey, A. S., Willsky, G. R., \& Takeuchi, E. S. (2007).Vanadium: chemistry, biochemistry, pharmacology and practical applications. Boca Raton, FL: CRC press.

Turnlund, J. R. (1999). Copper. In: M. E. Shils, J. A. Olson, M. Shike, A. C. Ross (Eds), Modern nutrition in health and disease (9th ed, pp. 241-252). Baltimore: Williams \& Wilkins.

Uganda National Bureau of Standards. (2006). Retrieved from

ftp://law.resource.org/pub/ug/ibr/us.203.2006.html, Assessed on 28-02-2019

United States Department of Agriculture [USDA]. (2015). Scientific Report of the 2015 Dietary Guidelines Advisory Committee: Advisory Report to the Secretary of Health and Human Services and the Secretary of Agriculture. Retrieved from https://health.gov/dietaryguideline s/2015-scientific-report/pdfs/scientific-report-ofthe-2015-dietary-guidelines-advisory-committee.pdf 
US EPA, (2015).Human Health Ambient Water Quality Criteria: 2015 Update, Retrieved from https://www.epa.gov/sites/production/files/2015-10/documents/human-health-2015-update-factsheet.pdf, Assessed on 28-02-2019, Assessed on 28-02-2019

Vowotor, M. K., Hood C. O., Owusu A., Akakpo E. H. and Mireku K. K., (2012). Determination of $\mathrm{Mn}, \mathrm{Cu}$, and $\mathrm{Na}$ in SarotherodonMelanotheron (Blackchin Tilapia) From the Fosu Lagoon, Cape Coast - Ghana, Using Instrumental Neutron Activation Analysis (INAA), The African Review of Physics, APR, 7, pp 367-375

Vowotor, M. K., Odumah Hood, C., Sackey, S. S., Owusu, A., Tatchie, E., Nyarko, S., \&Atieomo, S. M. (2014). An Assessment of Heavy Metal Pollution in Sediments of a Tropical Lagoon: A Case Study of the Benya Lagoon, Komenda Edina EguafoAbrem Municipality (KEEA) - Ghana. Journal of Health Pollution, 4(6), 26-39.

Wilson L. (2011). Copper toxicity syndrome. Retrieved from http://www.drlwilson.com/articles/copper_toxicity_syndrome.html, Assessed on 28-02-2019 